\title{
О некоторых особенностях анализа авторских паремий русского языка периода 1905-1907 годов
}

\section{About Some Features of the Analysis of Authorial Paroimias of the Russian Language of the Period of 1905-1907}

Артур Владимирович Загребельный

(Вологда, Россия)

\begin{abstract}
:
The article is devoted to the consideration of the research of such key features of authorial paroimias of the Russian language of the first Russian revolution period as the detailed analysis of the facts of socio-political life of the Russian society which caused the emergence of the new units of the language and the representation of meanings of all the components forming an authorial paroimia. The features of the research of the authorial paroimiology mentioned above are demonstrated at the example of the analysis of the authorial paroimia Tell me who you shoot at, and I will tell you who you are.
\end{abstract}

\section{Key words:}

authorial proverbs; methods of analysis; structural paroimiology; diachronic analysis; source proverb; anti-proverbs 
Научное лингвистическое исследование авторских паремий русского языка, образованных посредством структурно-смысловых трансформаций функционирующих в языке пословиц, поговорок и пословично-поговорочных выражений, началось сравнительно недавно - в середине 1990-х годов, причем эти исследования являлись, по большей части, синхронными [VALTER, MOKIJENKO 2005, 9; ANTONOVA 2011; KONSTANTINOVA 2009; BEGUN 2010].

Диахронические изыскания в области авторской паремиологии русского языка начала XX века в настоящее время все еще малопредставлены [ZAGREBEL'NYJ 2015; ZAGREBEL'NYJ 2017].

В ходе работы с различными источниками, в частности специальной литературой (архивными документами политических организаций, полиции, стенограммами выступлений депутатов в Государственной думе), художественной литературой, изданиями периодической печати, воспоминаниями и дневниковыми записями деятелей эпохи, нами было выявлено несколько десятков случаев употребления авторских пословиц, поговорок, пословично-поговорочных выражений (на Витте надейся, но погрома жди; Конституция не балалайка - поиграешь, на стену не повесишь; Корми сына до поры: вырастет в тюрьму на казенные хлеба сядет; Любишь печатать - люби и в кутузке сидеть; В чужой арсенал со своим пулемётом не суйся; Скажи, в кого ты стреляешь, а я скажу, кто ты; Кому жандарм, а тебе дяденька; Старого воробья на овсе не поймаешь; Каков кабинет, таков и бюджет; Не красна Москва домами, а кровавыми следами; На войско надейся, а сам уезжай; Не все то золото, ито лежит в Государственном банке; Бей, адмирал - наместником будешь и др.). Причем обнаружены все данные единицы были лишь в текстах одного типа источников - периодических печатных изданий (журналов общественно-политической сатиры), в рубрике «Новые пословицы». Особенностью выявленных авторских паремий является их единичное внеконтекстуальное употребление.

Вопросы изучения исторически дистанцированных авторских паремий неразрывно связаны с проблемой разработки методики их анализа, так как если методика анализа современных авторских паремий и их паремий-прототипов достаточно хорошо отработана, то «отточенной методики лингвистического анализа славянских пословиц в диахроническом аспекте... нам очень не хватает и, судя по всему, она ещё не скоро появится...» [MOKIJENKO 2010, 17].

Занимаясь на протяжении последних лет исследованием авторских паремий периода первой русской революции, мы выявили две ключевые особенности их анализа, которые, как нам представляется, будут в целом определять специфику разрабатываемой методики диахронического анализа данных единиц. К числу этих особенностей относятся расширенный блок анализа фактов социально-политической жизни российского общества, обусловивших появление новой 
паремии, и приведение значений всех образующих авторскую паремию слов-компонентов.

Наличие подробного культурно-исторического анализа, вскрытие глубинных причин, обусловивших создание новой паремии, позволяют компенсировать у современных носителей языка недостаток сведений об истории Российской империи начала XX века, что является принципиально важным, так как корректное восприятие содержания авторских паремий носителями языка возможно при условии наличия общих у адресата и адресанта знаний [GNEDAŠ 2010, 159].

Приведение значений образующих авторскую паремию слов-компонентов, а также формулирование механической суммы их значений (при наличии возможности) необходимо для определения типа авторской паремии. Конечно же, носитель языка неплохо представляет, что означает то или иное слово (тем более, если это слово входит в активный словарный запас), однако именно наличие столь подробного разбора позволяет на завершающей стадии анализа авторской паремии совершенно точно и на собственно научной основе определить её тип (пословица, поговорка либо пословично-поговорочное выражение) путем сопоставления выражаемого ей суждения и значений образующих её слов-компонентов (при данном сопоставлении легко выявляются первично и вторично маркированные слова-компоненты).

Рассмотрим отмеченные особенности на примере анализа авторской паремии Скажи, в кого ты стреляешь, а я скажу, кто ты [Zarnicy... 1906, 2].

Анализируемая авторская паремия образована на базе паремии-источника Скажи мне, кто твой друг, и я скажу тебе, кто ты, выражающей следующее суждение 'о человеке, его характере, устремлениях, моральных качествах, принципах и пр. можно многое сказать, если знать, с кем он дружит, с кем близок и т. д.' [SEROV 2004, 697]. Отсутствие в составе паремии-источника деактуализированных компонентов, аналитичный характер её значения, а также наличие только прямого плана содержания позволяют идентифицировать её как поговорку [ŽUKOV 200о].

Поговорка-источник Скажи мне, кто твой друг, и я скажу тебе, кто ты по своему происхождению является крылатым выражением, первоисточником которого считаются труды древнегреческого драматурга и поэта Еврипида. Широкую же известность крылатое выражение получило после его использования Сервантесом в тексте романа «Дон Кихот» [SEROV 2004, 697; BERKOV, MOKIJENKO, ŠULEŽKOVA 2000, 450]. В связи с тем, что в настоящее время в сознании большинства носителей языка утратилась связь между данным предложением и литературными источниками, их породившими, крылатое выражение перешло в группу поговорок [ŽUKOV 20oo]. 
Рассматриваемая авторская паремия Скажи, в кого ты стреляешь, а я скажу, кто ты образована посредством структурной трансформации паремии-источника, заключавшейся в замене слова-компонента, используемого для номинации источника сведений о человеке (друг), на слово-компонент, называющее производимое характеризуемым человеком действие (стрелять). Относительные местоимения (кто, кого), личное и притяжательное местоимения ( $m b l$, твой) выполняют функции уточнения, конкретизации.

Для уточнения типа исследуемой авторской паремии обратимся к её компонентному составу.

Глагол сказать имеет следующее значение: '1. Изложить устно какую-либо мысль; сообщить что-либо; произнести' [Slovar'... 1962, 870].

Предлог в употреблен для указания на объект, на который направлено действие [Slovar'... 1951, 6].

Употребленное дважды относительное местоимение кто (в первом случае в форме вин.п. ед.ч., во втором - в форме им.п. ед.ч.) использовано в качестве союзного слова для присоединения изъяснительного придаточного предложения [Bol'šoj... 2007, 733].

Лично местоимение ты '2. Употребляется для обозначения человека вообще, какой-либо неопределенной группы лиц' [Slovar'... 1963b, 1187].

Слово стрелять, употребленное в форме 2-го л. ед. ч., имеет следующее понятийное наполнение: '1. Производить выстрелы' [Slovar'... 1963a, 1033].

Союз $a$ 'II. 5. Присоединяет к предшествующему предложению по связи с каким-либо словом или группой слов (которые при этом повторяются) другое предложение, выражающее дальнейшее развитие мысли' [Slovar'... 1950, $5]$.

В итоге механическая сумма значений слов-компонентов авторской паремии может быть представлена в следующем виде: 'сообщи, в каких людей ты производишь выстрелы, а я скажу, кто ты'. Как известно, любая паремия выражает суждение, которое не равняется простой сумме лексических значений образующих её слов (как переосмысленных, так и сохранивших свое основное языковое значение), а представляет собой расширительное толкование в форме предложения, которое может как основываться на значениях слов-компонентов и включать данные слова в свой состав, так и не иметь никакой прямой связи с данными словами в их основных языковых значениях.

Определение типа паремии напрямую связано с выражаемым ей суждением. Так, если в суждении присутствуют слова, образующие данную паремию, то перед нами либо поговорка, либо пословично-поговорочное выражение. Если же таких слов в суждении нет, то тип паремии определяется как пословица [ŽUKOV 2000, 13-14]. 
В связи с тем, что паремии «обнаруживают свой смысл лишь в ... контексте, то кроме логического описания содержания ... требуется контекстуально-ситуативная их характеристика» [ŽUKOV 200о, 14]. Для уточнения типа анализируемой паремии и формулировки выражаемого ей суждения обратимся к анализу внеязыковых факторов, обусловивших появление данной единицы.

Первая половина 1906 г. была тяжелым временем в истории России: «Восстание потерпело неудачу (имеется в виду декабрьское вооруженное восстание в Москве - уточнение наше - A. 3.), началась тяжелая полоса реакции, гр. С. Витте, ближайший виновник манифеста 17 октября, умалился, Дурново возвеличился; после растерянности ноября и начала декабря правительство стало чувствовать себя бодрее, конституционные предрассудки потеряли для него всякую силу...» [JEZERSKIJ 1907, 5]. В большинстве регионов страны было объявлено военное положение [Žurnal... 1906; ŠAUROV 1974].

Леворадикальные политические силы продолжали вести вооруженную борьбу с царской властью и созданными ей боевыми структурами ультраправых политических партий. Стрельба на улицах городов, деревень и сел была привычным делом [ŠAUROV 1974]. Историки отмечают, что «весенне-летний подъём 1906 г. уступал по своим масштабам только высшему подъёму революции в октябре-декабре 1905 г.» [DERENOVSKIJ, TJUTJUKIN 1975, 92]. Власть же всеми доступными средствами подавляла выступления граждан, причем уже с начала 1906 г. изменился объект правительственных репрессий: «Не традиционный студент или интеллигент подвергался теперь преследованию, а рядовой рабочий, подлинный пахарь: народ почувствовал на себе самом всю тяжесть политического бесправия» [JEZERSKIJ 1907, 14].

В 1906 г. широкое распространение получила практика политических убийств и индивидуального террора. Так, например, в убийстве члена конституционно-демократической партии М.Я. Герценштейна подозревали членов боевого подразделения Союза русского народа. Этот случай был достаточно резонансным, что неудивительно: устранение столь известного и влиятельного политика в очередной раз доказало неспособность царской власти навести в стране порядок, обеспечить незыблемые права человека, в том числе право на жизнь. Л. А. Тихомиров в этой связи в своей дневниковой записи от 19 июля 1906 г. отметил следующее: «В газетах явилось известие об убийстве Герценштейна (бывшего депутата) в Терионах. Случай поразительный, который, очевидно, не может быть ничем, кроме политического убийства. Но значит, это дело какого-нибудь «черносотенца»? Неужели мы дожили до двойного террора, и слева и справа?» [TICHOMIROV, REPNIKOV, KOTOV 2015, 257].

Таким образом, разделяя мнение В. П. Жукова о том, что толкование пословиц, поговорок и пословично-поговорочных выражений должно осуществляться 
через предложение по принципу «подобное - подобным» [ŽUKOV 20оo], суждение, выражаемое анализируемой паремией и сформулированное с учетом значений образующих её слов и обусловивших её появление факторов внешней среды, может быть представлено в следующем виде: 'о принадлежности человека к той или иной политической партии, его характере, моральных качествах и т. п. можно многое сказать, зная против кого он ведет вооруженную борьбу'. Отсутствие в составе авторской паремии деактуализированных компонентов позволяет отнести её к поговоркам.

Как видим, замена слова-компонента друг, значение которого характеризуется наличием положительной семы рациональной оценки (друг - '1. Лицо, тесно связанное с кем-либо взаимным доверием, преданностью, любовью; приятель' [Slovar'... 1954, 1128]. Семы 'доверенность', 'преданность', 'любовь' определяют наличие в околоядерной части денотативного блока значения слова микрокомпонента 'положительная' 'оценка'), на слово-компонент стрелять, значение которого содержит потенциально отрицательные (не актуализированные) оценочные и эмотивные семы, обусловила усиление образности авторской паремии при одновременном расширении перечня характеристик человека, которые могут быть даны ему на основе знаний о принадлежности лиц, с которыми данный человек ведет вооруженную борьбу, к конкретным политическим силам.

Подводя итог, можем отметить, что учет двух обозначенных выше особенностей анализа авторских паремий (особенностей, выявленных автором в ходе проведенных ранее исследований и продемонстрированных в данной статье на примере анализа одной авторской паремии) исторически дистанцированных эпох может в перспективе послужить одной из основ разрабатываемой в науке комплексной методики их диахронического анализа. Создание и повсеместное использование подобной методики в практике изучения авторской паремиологии будет способствовать расширению и углублению наших знаний о процессах формирования новых паремий, потенциальных возможностях языковой системы, взаимовлиянии социума и языка, соотношении языка и речи. 


\section{Библиография:}

ANTONOVA, O. N. (2011): Izmenenije komponentnogo sostava kak vid transformacii paremij (na materiale anglojazyčnych massmedia). Vestnik Burjatskogo gosudarstvennogo universiteta, 2011, № 11, s. 3-5.

BEGUN, V.V. (2010): Reklamnyj slogan kak transformacija kul'turnych stereotipov. Vestnik Permskogo universiteta. Rossijskaja i zarubežnaja filologija, 2010, № 1 (7), s. 31-37.

BERKOV, V. P., MOKIJENKO, V. M., ŠULEŽKOVA, S. G. (2000): Bol'šoj slovar' krylatych slov russkogo jazyka: okolo 4 ooo jedinic. Moskva.

Bol'šoj akademičeskij slovar' russkogo jazyka. Tom 8. Kajuta-Kjuriny. (2007). Moskva.

DERENOVSKIJ, G. M., TJUTJUKIN, S. V. (1975): Rabočij klass v revoljucii 1905-1907 gg. In: Istoričeskije zapiski. K 7o-letiju pervoj russkoj revoljucii. Moskva.

JEZERSKIJ, N. F. (1907): Gosudarstvennaja Duma pervogo sozyva. Penza.

GNEDAŠ, S. I. (2010): Proverbial'nyje jedinicy i vozmožnosti ich transformacii v sovremennom nemeckom jazyke. Vestnik Čuvašskogo universiteta, 2010, № 2, s. 155-159.

KONSTANTINOVA, A. A. (2009): Poslovicy i pogovorki $v$ sovremennoj anglo-amerikanskoj presse: avtorskoje ispol'zovanije tradicionnych paremij. Vestnik Tomskogo gosudarstvennogo universiteta, 2009, Tom 322, s. 22-25.

MOKIJENKO, V. M. (2010): Sovremennaja paremiologija (lingvističeskije aspekty). Mir russkogo slova, Tom 3, 2010, № 3, s. 6-20.

SEROV, V. V. (ed.) (2004): Ėnciklopedičeskij slovar' krylatych slov i vyraženij. Boleje 4000 statej. Moskva.

Slovar' sovremennogo russkogo literaturnogo jazyka. Tom 1. A-B. (1950). Moskva-Leningrad.

Slovar' sovremennogo russkogo literaturnogo jazyka. Tom 2. V. (1951). Moskva-Leningrad.

Slovar' sovremennogo russkogo literaturnogo jazyka. Tom 3. G-fe. (1954). Moskva-Leningrad.

Slovar' sovremennogo russkogo literaturnogo jazyka. Tom 13. S-Snjat'sja. (1962). Moskva-Leningrad.

Slovar' sovremennogo russkogo literaturnogo jazyka. Tom 14. So-Sjam. (1963a). Moskva-Leningrad.

Slovar' sovremennogo russkogo literaturnogo jazyka. Tom 15. T. (1963b). Moskva-Leningrad.

ŠAUROV, I. V. (1974): Vospominanija učastnika pervoj russkoj revoljucii. Moskva.

TICHOMIROV, L. A., REPNIKOV, A. V., KOTOV, B. S. (eds) (2015): Dnevnik L. A. Tichomirova. $1905^{-1907} \mathrm{gg}$. Moskva. 
VALTER, Ch., MOKIJENKO, V. M. (2005): Antiposlovicy russkogo naroda. Sankt-Peterburg.

ZAGREBEL'NYJ, A. V. (2015): Avtorskije paremii v russkom jazyke načala XX veka. Voprosy filologii, 2015, Tom 3, s. 39-47.

ZAGREBEL'NYJ, A. V. (2017): Revoljucija 1905-1907 gg. v zerkale avtorskoj paremiologii russkogo jazyka. Vestnik Nižegorodskogo universiteta im. N. I. Lobačevskogo, 2017, Tom 3, s. 221-230.

Zarnicy. Žurnal literaturno-chudožestvennyj i satiričeskij. 1906, № 3. ŽUKOV, V.P. (2000): Slovar' russkich poslovic i pogovorok. Moskva.

Žurnal sojedinennogo soveščanija S.-Peterburgskogo i Moskovskogo otdělenij central'nogo komiteta «Sojuza 17 oktjabrja», prochodivšego v Moskve 8 i 9 janvarja 1906 goda. Zasedanije 8 janvarja. (1906). In: Partija «Sojuz 17 oktjabrja». Protokoly s"jezdov, konferencij i zasedanij CK. V 2-ch tomach. T. 1. Protokoly s"jezdov i zasedanij CK. 1905-1907 gg. Moskva, s. 45-6o.

\section{Об авторе}

Artur Vladimirovich Zagrebel'nyi, Vologda Research Center of the Russian Academy of Sciences, Department of Editorial-and-Publishing Activity and Science-Information Support, Vologda, Russian Federation, pechorin2106@mail.ru 